\title{
EFFECT OF ANNEALING CYCLES ON DEEP DRAWABILITY OF LOW CARBON TITANIUM ADDED STEEL
}

\author{
Iskandar Muda ${ }^{1}$ and Azwar Manaf ${ }^{2}$ \\ ${ }^{1}$ Metallurgical Engineering Dept., Faculty of Manufacture Engineering \\ Universitas Jenderal Achmad Yani \\ Jl. Jend Gatot Subroto, Bandung 40285 \\ ${ }^{2}$ Graduate Study in Materials Science Program, Faculty of Mathematics and Natural Sciences \\ Universitas Indonesia \\ New Campus UI Depok, Jawa Barat 16424 \\ E-mail: azwar@ui.ac.id
}

Received: 4 October 2019

Revised: 10 December 2019

Accepted: 7 January 2020

\begin{abstract}
EFFECT OF ANNEALING CYCLES ON DEEP DRAWABILITY OF LOW CARBON TITANIUM ADDED STEEL. Maximum mechanical properties and deep drawability of low carbon titanium added steels was obtained after heat treatment with simulation batch annealing cycles in an industrial process. The effect of holding times and holding temperatures on deep drawability were studied using tensile test for measuring normal anisotropy (r-value) and strain hardening exponent (n-value). Scanning electron microscope were employed for observation of microstructure in steel sheets. X-ray diffraction with pole figure techniques were also used for measuring texture of annealing. Results showed that as the temperature was increased up to $900{ }^{\circ} \mathrm{C}$, both $\mathrm{r}$ and $\mathrm{n}$ values increased gradually and peaked in the temperature of $850^{\circ} \mathrm{C}$. This results showed that formability of sheet materials increased until batch annealing temperature reach $850{ }^{\circ} \mathrm{C}$ as increasing the ratio of intensities $\{111\}<112>/\{100\}<110>$. The largest mean $\mathrm{r}$ value of almost 2.6 was obtained in slow heating at holding temperature of $850^{\circ} \mathrm{C}$ with $\mathrm{n}$ value of $\sim 0.27$.
\end{abstract}

Keywords: Low carbon, Titanium, Recrystallization, Texture, Deep drawability

\begin{abstract}
ABSTRAK
PENGARUH SIKLUS PEMANASAN TERHADAP KEMAMPUAN DAPAT DIBENTUK PADA BAJA KARBON RENDAH YANG DITAMBAHKAN TITANIUM. Sifat Mekanik dan kemampuan dapat dibentuk secara maksimum untuk baja karbon rendah yang ditambahkan titanium, diperoleh setelah perlakuan panas dengan dilakukan simulasi siklus anil tipe batch sesuai dengan skala industri. Pengaruh waktu penahanan dan temperatur penahanan terhadap mampu dibentuk dipelajari dengan pengujian menggunakan uji tarik untuk mengukur anisotropi normal (nilai-r) dan eksponen pengerasan regangan (nilai-n). Mikroskop elektron skaning digunakan untuk pengamatan struktur mikro pada lembaran baja. Difraksi sinar-X dengan teknik pole figure juga digunakan untuk mengukur tekstur rekristalisasi setelah proses aniling. Hasilnya menunjukkan bahwa dengan meningkatnya temperatur sampai $900{ }^{\circ} \mathrm{C}$, maka nilai-r dan nilai-n meningkat secara bertahap dan memuncak pada temperatur $850^{\circ} \mathrm{C}$, selanjutnya turun kembali pada temperatur $900^{\circ} \mathrm{C}$. Hasil ini menunjukkan bahwa kemampuan dibentuk bahan lembaran menunjukkan peningkatan dengan temperatur anil batch hingga $850^{\circ} \mathrm{C}$ seiring dengan peningkatan rasio intensitas $\{111\}<112>/\{100\}<110>$. Nilai $r$ rata-rata terbesar adalah hampir 2,6 dan nilai n adalah 0.27 diperoleh dalam pemanasan lambat pada temperatur penahanan $850^{\circ} \mathrm{C}$.
\end{abstract}

Kata kunci: Karbon kadar rendah, Titanium, Rekristalisasi, Tekstur, Deep drawability 


\section{INTRODUCTION}

Titanium addition and continuous annealing cycles optimization are used to improve the deep drawability of low carbon steels. Deep drawability is achieved using low carbon contents as well as alloying additions, such as titanium, which tie up interstitial solute atoms, such as carbon and nitrogen as the example given in the enamel product.[1-3] Increasing deep drawability in low carbon steel with added titanium was due to recrystallization texture $\{111\}<110>$ with high intensity an lower on texure $\{100\}<110>[1-3]$.

Previous works on continuous annealing cycles on of ultra low carbon have been limited, therefore the investigation of mechanical properties and deep drawability effect from batch annealing cycle on of low carbon titanium added steel will be explained in the present paper. Furthermore, the formation of recrystallization texture and direct observation of fractured precipitates were investigated.

The fractured precipitates are favorable because it formed microstructure void for hydrogen to fill in the low carbon steel with titanium addition and prevent fishscale defect on enameling process.

\section{EXPERIMENTAL METHOD}

\section{Materials and Instruments}

In order to obtain a comparison of steel drawability from different steel materials, the samples were obtained from Krakatau Steel. The samples were heated in tube furnace in Krakatau Steel laboratory and characterized in X-Ray Diffraction XRD-7000- Shimadzu Scientific Instruments with pole figure. The slabs dimension is $20 \mathrm{~cm} \times 90 \mathrm{~cm} \times 600 \mathrm{~cm}$. Tensile strength, scanning electron microscope were tested in Krakatau Steel laboratory. The steel used in this investigation was low carbon titanium added steel sheets. Table I showed the average elemental compositions of the steel samples.

Table 1. Chemical composition of steel ( $\%$ by weight)

\begin{tabular}{cccccccc}
\hline $\mathrm{C}$ & $\mathrm{Si}$ & $\mathrm{Mn}$ & $\mathrm{P}$ & $\mathrm{S}$ & $\mathrm{Al}$ & $\mathrm{Ti}$ & $\mathrm{Fe}$ \\
0.009 & 0.015 & 0.12 & 0.003 & 0.014 & 0.04 & 0.057 & $\mathrm{Bal}$ \\
\hline
\end{tabular}

\section{Method and Procedure}

Steel scraps, sponge irons and Calcium Oxide $(\mathrm{CaO})$ melted in the electric arc furnace at the temperature $1600{ }^{\circ} \mathrm{C}$. After rinsing, Vacuum degassing process and alloying with added Titanium from ferrotitanium, the steel was cast in a casting machine. Then the sample was reheated in a slab reheating furnace in Hot Strip Mill (HSM) at temperature $1220^{\circ} \mathrm{C}$.

HSM was operated with finishing temperature $890{ }^{\circ} \mathrm{C}$ and coiling temperature $580{ }^{\circ} \mathrm{C}$. In cold rolling mill process, hot band coils were pickled in continuous pickling line to remove scale, followed by reduction of thickness in Tandem Cold Mill (TCM) with reduction ratio up to $73.3 \%$. The processes mentioned prior was followed production flow scheme in PT Krakatau Steel.

Rectangular samples (240 mm x $33 \mathrm{~mm}$ x $0.7 \mathrm{~mm}$ ) were cut from the full hard sheet were heated slowly $\left(12^{\circ} \mathrm{C} /\right.$ hour $)$. The samples were annealed for $6-12$ hours at $700^{\circ} \mathrm{C}-900^{\circ} \mathrm{C}$ in an argon gas atmosphere as protective gas. Chloride acid $(\mathrm{HCl})$ was used to remove any remaining oxide scales on annealed samples in the tube furnace.

The mean $r$-value obtained from tensile test was used to investigate the deep drawability of the steel. The key of increasing drawability properties are increasing $r$-value and $n$-value, higher the value it will increasing deep drawability. The annealed steel sheet was shaped as a tensile specimen with a gauge length and width 50 and $25 \mathrm{~mm}$, respectively. JIS No. 5 was used as standard to determine r-value, the testing followed tensile test standard ASTM A283. The samples were elongated by $15 \%$ and then using measurements of the width in ten locations.

Before $\left(\mathrm{w}_{\mathrm{o}}\right)$ and after test with elongation $\left(\mathrm{w}_{15 \%)}\right.$ in Equation 1.

$$
r=\frac{\varepsilon_{w}}{\varepsilon_{h}}=\frac{\ln \left(\frac{w_{o}}{w_{15 \%}}\right)}{\ln \left(\frac{l w_{o}}{l w_{15 \%}}\right)}
$$

Tensile test was done on the $0^{\circ}$ rolling direction (L), on $45^{\circ}$ diagonal direction (D) and $90^{\circ}$ transversal direction $(\mathrm{T})$ relative to the Rolling direction (Figure 1)

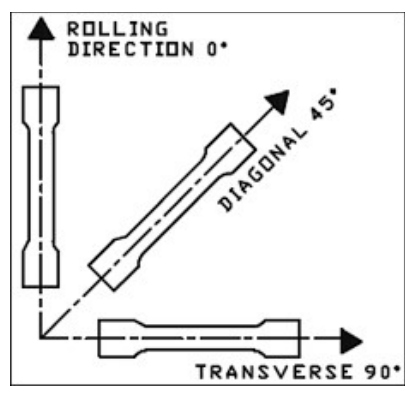

Figure 1. The testing position of deep drawability sample.

An average value of $r$ was determined from Equation 2.

$$
r=\frac{\left(r_{L}+2 \cdot r_{D}+r_{T}\right)}{4}
$$

The strain hardening exponent, n-value, of each sampel was calculated using the measured stress at $10 \%$ elongation. The ultimate strength was referred to NelsonWinlock table.

Metallographic analysis was conducted using optical microscopy, scanning electron microscopy and 
EDS. The quantitative metallographic analysis on average grain size measurement was based on ASTM E 112. Recrystallization texture from annealed steel was investigated using sample with dimension of $19 \mathrm{~mm}$ x $19 \mathrm{~mm}$ thickness. The samples were polished and measured with X-ray diffraction with the Schulz method, dan dengan option pole figure. Plane of $\{110\}$ pole figures were determined using Mo radiation which rotate from $5^{\circ}$ to $70^{\circ}$, while the sample mounted stationary (Figure 2)

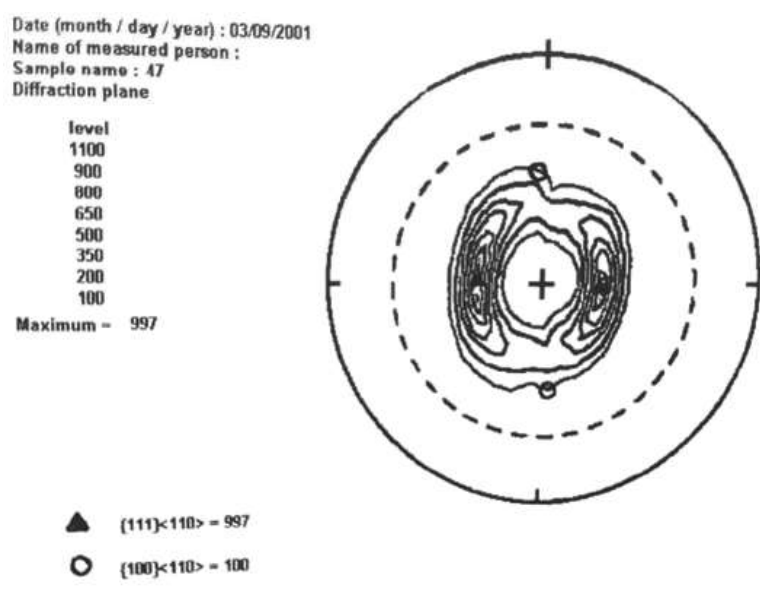

Figure 2. Pole Figure sample with annealing cycle temperature of $750{ }^{\circ} \mathrm{C}$ holding time 10 hours.

\section{RESULT AND DISCUSSION}

\section{Effect of Annealing Temperature on Mechani- cal Properties}

Figure 3 depicted the relationship between temperature and annealing process. This figure showed that with increased temperature, the tensile strength decreases.

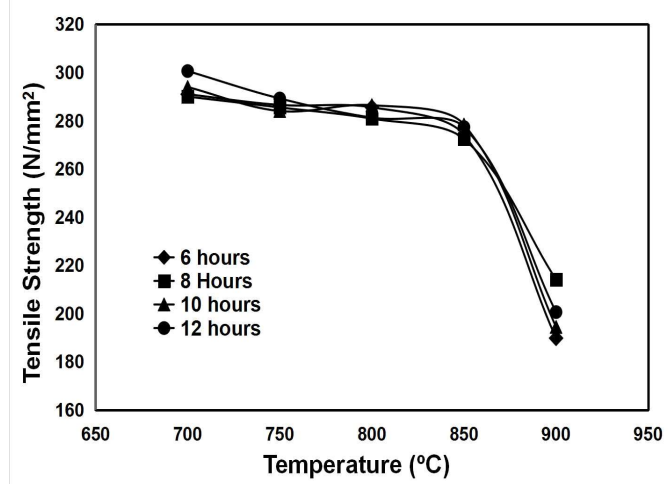

Figure 3. Effect of temperature on tensile strength of low carbon titanium added steel.

The significant decreased were showed from temperature $850^{\circ} \mathrm{C}$ to $900{ }^{\circ} \mathrm{C}$. Furthermore, the yield strength also decreased with increasing temperature. However, the yield strength value drop was not as significant as the tensile strength as shown in the Figure 4. In case of the abruptly tensile and yield strength of higher temperature $\left(900^{\circ} \mathrm{C}\right)$, presumably do to ferrite to austenite transformation, resulted the recrystallization texture is randomized by complete $\gamma+\alpha$ transformation.[12].

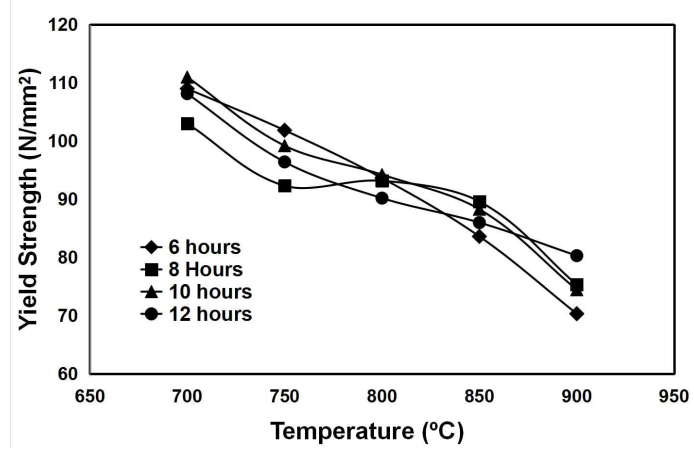

Figure 4. Effect of temperature on yield strength of low carbon titanium added steel.

Alternatively, the elongation was increasing the ductility until $850^{\circ} \mathrm{C}$, then declined significantly at the temperature of $900{ }^{\circ} \mathrm{C}$ as depicted in Figure 5. In contrast, Figure 6 illustrated the increasing temperature was decreasing the hardness of the sample.

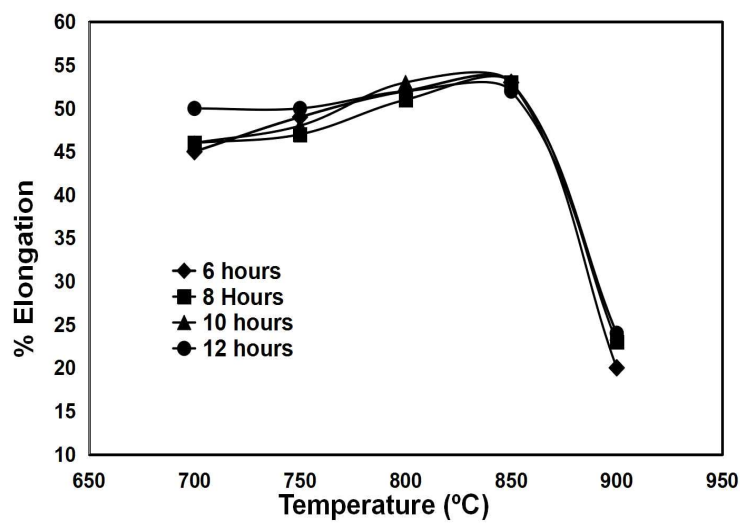

Figure 5. Effect of temperature on elongation of low carbon titanium added steel.

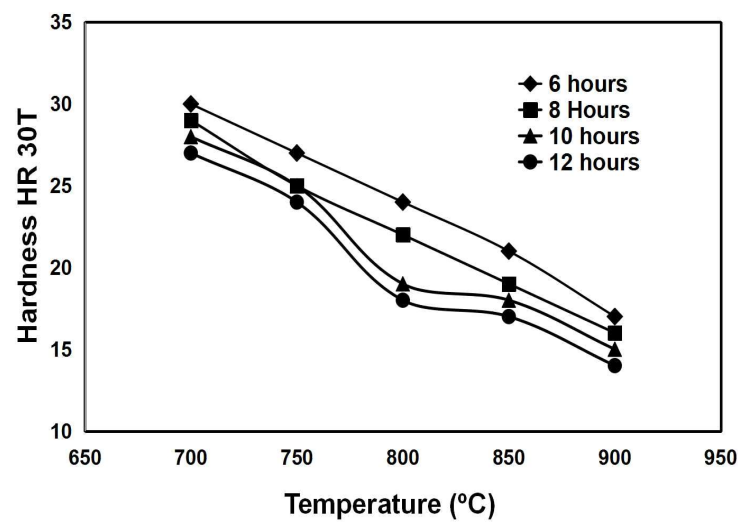

Figure 6. Effect of temperature on hardness of low carbon titanium added steel. 


\section{Effect of Annealing on Deep Drawability}

The changes in normal anisotropy (mean $r$-value) after annealing are shown in Figures 7. It shows the relationship between the temperature on r-value for different holding times. The trend of r-value showed that the effect of holding temperature and holding time on drawability indicated the r-value increased gradually as the temperature increased up to $850{ }^{\circ} \mathrm{C}$, after which it is abruptly decreased. For long holding time, the r-value is higher than short holding time for steel used with holding time $6,8,10$ and 12 hours.

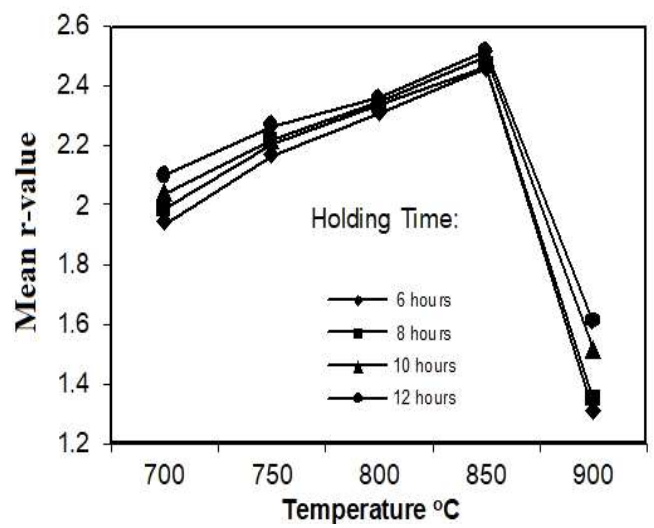

Figure 7. Effect of temperature on mean r-value of low carbon titanium added steel.

In the case of the increase r-value of higher temperature $\left(900^{\circ} \mathrm{C}\right)$, presumably do to ferrite to austenite transformation, resulted the recrystallization texture is randomized by complete $\gamma+\alpha$ transfor mation [12].

The effect of annealing temperature on the grain size low carbon Ti added is shown in Figure 8. With increasing annealing temperature and holding time increases the grain size. It was evident that for temperature-holding $900^{\circ} \mathrm{C}$ The biggest grain size increase, presumable due to ferrite to austenite transformation in this temperature. This is consistent with reports by Inagaki [4] and Okamoto et al [5].

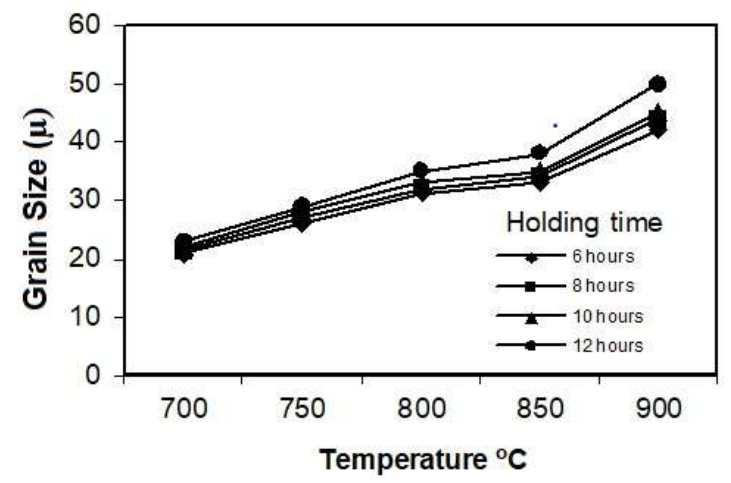

Figure 8. Effect of temperature on grain size of low carbon titanium added steel.
Figure 9 shows effect of holding temperature on $\mathrm{n}$-value, this is shown from the curve that longer holding time and higher temperature holding result in higher nvalue except for $900^{\circ} \mathrm{C}$ are significantly lower than $\mathrm{n}$ value below $850^{\circ} \mathrm{C}$ for all of steel used. The effect of annealing temperature on properties of interstitial free steel through continuous annealing has been well documented [11-14] All authors show that r-value increases with increasing annealing temperature with range $760^{\circ} \mathrm{C}-845^{\circ} \mathrm{C}$ of $\mathrm{Ti}, \mathrm{Nb}-\mathrm{Ti}$ and $\mathrm{Nb}$ IF steel, while for range $870-940^{\circ} \mathrm{C}$, above which the r-value drops precipitously due to ferrite to austenite transformation.

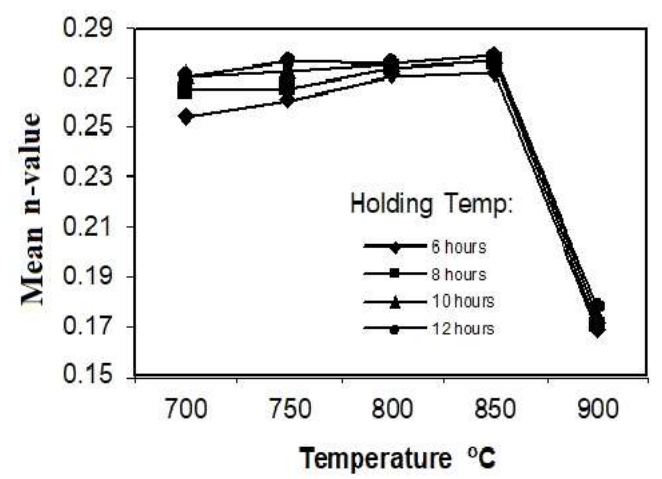

Figure 9. Effect of temperature on n-value of low carbon titanium added steel.

This results showed that $\mathrm{r}$-value increased only in the austenite area [12]. In contrast with high strength steels, for which the $r$ value increases even when annealing in the austenite region.

The preferred orientation of the ferrite formed from transformation of austenite is attributed to residual stress. The amount of residual stress in low carbon steels is small, so the ferrite formed from transformation of austenite is relatively randomized [12]

\section{Effect of Annealing on Texture}

The increase in anisotropy is presumably due to the development of preferred crystallographic orientation during rolling and annealing. Specifically,

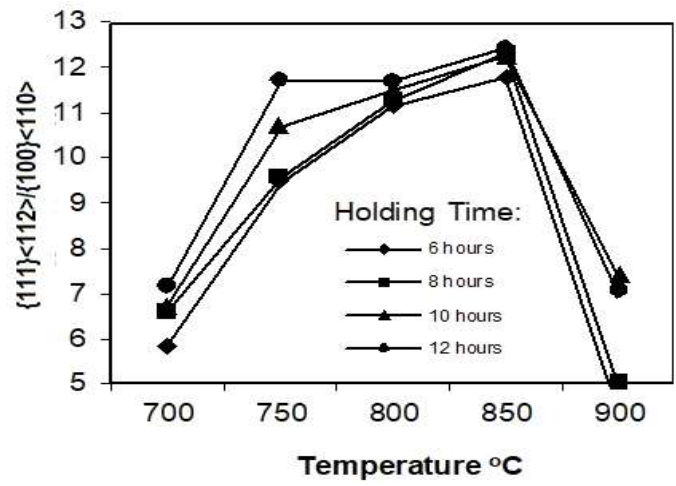

Figure 10. Effect of temperature on preferred orientation of low carbon titanium added steel. 
materials with a $\{111\}<112>$ texture exhibit strong anisotropy [13-15].

Thus, in this work, Figure 10 shows that the degree of texture in the low carbon titanium added increases with increasing annealing temperature, except for annealed at $900^{\circ} \mathrm{C}$. This steel in the ferrite + austenite region could have led to the observed reduction in preferred orientation and accompanying properties.

\section{Effect of Annealing on Precipitates}

The scanning electron micro-graphs of low carbon titanium added, are shown in Figure 11. The finding precipitates in low carbon titanium added at three forms, the first form is rectangular and the some angle the finding void.
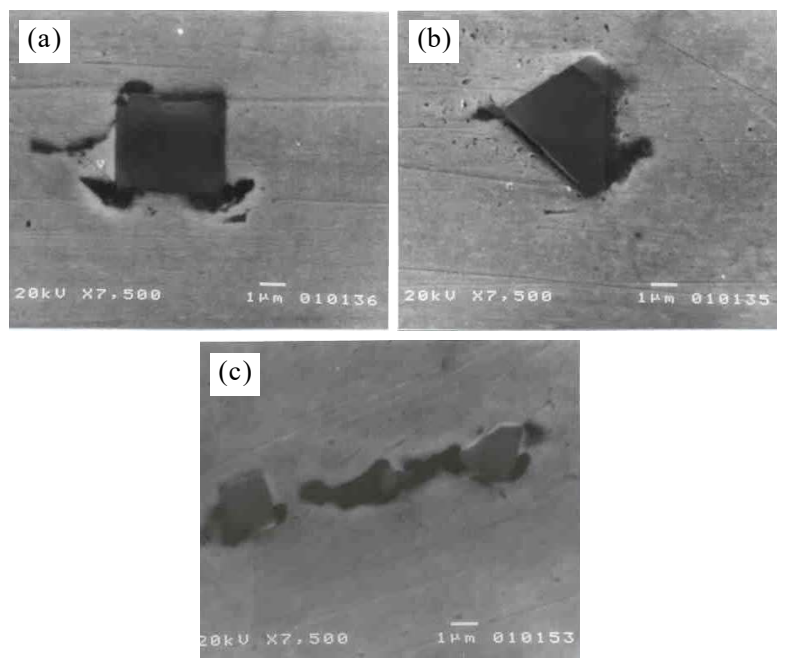

Figure 11. Scanning Electron Micrographs of precipitates, a) rectangular, b) triangular and c) fracture form on low carbon titanium added steels.

The size of precipitate is from $10-12 \mu \mathrm{m}^{2}$, with uniform distribution inside the steel. Annealing cycle did not change the size of precipitate because the precipitate was formed prior the anealling cycle. The precipitate was intentionally formed for the site of void formation. This void was a solution to solve fish scale in enameled product.

The second form is triangular and around this precipitate the finding void. The third form is precipitates broken into many pieces and around of precipitate finding void. The chemical composition of the precipitates and void regions as determined by energy dispersive X-ray spectroscopy (Table II), these results indicate that $\mathrm{Ti}(\mathrm{C}, \mathrm{N})$ forms in the LC Ti added. The voids contain aluminum oxide and traces of sulfides. This is consistent with other researchers who observe carbon/nitrogen-containing $(\mathrm{TiC}, \mathrm{TiN}, \mathrm{Ti}(\mathrm{C}, \mathrm{N}))$ and sulfur-containing phases ( $\mathrm{TiS}$ and $\mathrm{Ti}_{4} \mathrm{C}_{2} \mathrm{~S}_{2}$ ) in low carbon titanium added, $[1,8,9,16]$. The alumina is presumably from particles incorporated in the voids during polishing.

Fish scale defects were not observed in the enamel coatings on any of the steels indicating that the voids were sufficient to accommodate evolved hydrogen. However, customer report from PT. Krakatau Steel not reported complaint regarding the fishscale defect.

Table 2. Chemical composition of precipitates and void determined from SEM, Include EDS output.

\begin{tabular}{cccc}
\hline & Content & Void & Precipitate \\
\hline & $\mathrm{C}$ & 40 & 31 \\
& $\mathrm{O}$ & 40 & - \\
Weight & $\mathrm{Al}$ & 5 & - \\
Percent & $\mathrm{S}$ & $<1$ & - \\
& $\mathrm{Fe}$ & - & - \\
& $\mathrm{Ti}$ & 3 & 33 \\
& $\mathrm{~N}$ & - & 36 \\
& $\mathrm{P}$ & - & - \\
\hline
\end{tabular}

\section{CONCLUSION}

The effect of temperature annealing, holding time during batch annealing simulation on the recrystallization behavior of low carbon titanium added cold rolled sheet steels were investigated as follows, The effect of holding temperature on formability, the $r$ value and n-value large when holding temperature below $850^{\circ} \mathrm{C}$ and abruptly decreased at temperature $900^{\circ} \mathrm{C}$.

In case of the abruptly formability of higher temperature $\left(900^{\circ} \mathrm{C}\right)$, presumably do to ferrite to austenite transformation, resulted the recrystallization texture is randomized by complete $\gamma+\alpha$ transformation. The chemical composition of the precipitates indicate that $\mathrm{Ti}(\mathrm{C}, \mathrm{N})$ forms in the LC Ti added and the voids contain aluminum oxide.

\section{ACKNOWLEDGMENT}

The authors gratefully acknowledge PT Krakatau Steel Cilegon for providing material and research facilities.

\section{REFERENCES}

[1]. H. Takechi: ISIJ International, vol 34, No 1, pp 1, 1994.

[2]. R. Yoda, I. Tsukatani, T Inoue and T. Saito: ISIJ International, vol 34, No 1, pp 72, 1994.

[3]. K. Tsunoyama, T. Obara, S. satoh, H. Abe, O. Shibasaki and N. Uesugi: "Development of Extra Deep Drawing Cold Rolled Sheet Steels for Integrated Automotive Parts" Kawasaki Steel Technical Report No 24 April 1991.pp. 89.

[4]. R.K. Ray, Textures in Materials Research, Science Publishers, Inc, Enfield, New Hampshire, pp. 331, 1999. 
[5]. T. Urabe and J. J. Jonas: ISIJ International, vol 34, No 1, pp $441,1994$.

[6]. Inagaki: ISIJ International, vol 34, No 1, pp $317-$ 319, 1994.

[7]. A. Okamoto and N. Mizui: Metallurgy of Vacuum Degassed Steel Products, Pradhan editor, TMS, Indianapolis, pp $170-17,1990$

[8]. D. J. Blickwede, Transaction of the ASM, vol 61, pp 662-663, 1968

[9]. S. R. Goodman, P. R. Mould and J. C. Siple: R Pradhan editors, TMS-AIME, Warrandale. PA., pp167, 1985

[10]. S. Satoh, T. Boar, M. Nishida and T. Irie: Trans ISIJ, vol 24, pp 838-846. 1984.

[11]. Gupta, T. Parayil and L. T. Shiang: TMS-AIME, Warrandale, PA,pp 139-153, 1988.
[12]. N. Yoshinaga, K. Ushioda, A Itami and O. Akisue: ISIJ Internationa, 34, No 1, 1994.

[13]. S. V. Subramanian and J. Gao: International Forum for Physical Metallurgy of IF Steels, the Iron and Steel Institute of Japan, Tokyo, pp 56, 1994.

[14]. M.Takahashi et. al. "Metallurgical Approaches for Product Development and Process Optimization." Nippon Steel Technical Report No 101, pp. 128137, 2012

[15]. Y. Ping. et.al. "Formation of the $\{111\}<110>$ Annealing Texture in Steels" Transactions of Materials and Heat Treatment, Vol 30 (3), pp 46-52, 2009.

[16]. M. Hua, C.I. Garcia and A.J. DeArdo: Metall. Mater. Trans. Vol. 28A, pp 1777, 1997. 